This is the accepted version (pre-copyedited) of a contribution published in Advances in Production Management Systems. Initiatives for a Sustainable World. APMS 2016. IFIP Advances in Information and Communication Technology.

The final publication is available at Springer via https://doi.org/10.1007/978-3-319-51133-7_63

Refer to the published version for citation:

Li Y., Holgado M., Evans S. (2016) Business Model Innovation in State-Owned and Private-Owned Enterprises in China. In: Nääs I. et al. (eds) Advances in Production Management Systems. Initiatives for a Sustainable World. APMS 2016. IFIP Advances in Information and Communication Technology, vol 488. Springer, Cham

\title{
Business model innovation in state-owned and private- owned enterprises in China
}

\author{
Yan $\mathrm{Li}^{1{ }^{1,}}$, Maria Holgado ${ }^{2}$, Steve Evans ${ }^{2}$ \\ ${ }^{1}$ Institute for Manufacturing. University of Cambridge \\ 17 Charles Babbage Road, CB3 0FS Cambridge (UK) \\ $\{$ yl483, mh769, se321\}@cam.ac.uk
}

\begin{abstract}
The aim of the paper is to identify the complexity of policy execution, investment and financial support between state-owned and private-owned enterprises in China. Based on the literature review of business model innovation, and current situation of private-owned and state-owned enterprises in China, there is a lack of evidence and case analysis in the power of policy execution and the version of future development between two kinds of industries. The authors conducted qualitative research in four typical industries. Two of them are private-owned and the others are state-owned. The research aims to make a specific comparison between two kinds of industries in China.
\end{abstract}

Keywords: Business Model, Business Model Innovation, Private-owned enterprise, State-owned enterprise, China

\section{Introduction}

Over the past decade, market competition has become fiercer, especially at a global scale, with an enormous percentage of large-scale enterprises facing a great challenge for surviving, let alone small and medium companies. High market competition together with sustainability-related social, legal, political and economic requirements has increased the importance of corporate sustainability strategies (Schaltegger et al., 2012). Ultimately, business model innovation emerges as a significant concept for supporting value creation and improving the core competitiveness for companies. It is especially relevant in current moments of economic distress (Amit and Zott, 2010).

Business model innovation, however, may not represent something easy or straightforward to be realized as often implies a remarkable change to get the innovated "revolution" adopted in the enterprise. Additionally, the possibilities and capacity to perform the business model innovation may differ for different types of companies. Organizational culture and structure would influence the process and outcomes of innovations targeting companies; business model (Bock et al., 2012). In this regard, small and medium companies may lack the necessary resources already in place to perform the innovation but, on the contrary, may be more agile to reach rather than large companies. An unexplored potential difference on the approach towards business model innovations is also present when considering different types of ownership, i.e. state-owned versus private owned enterprises. This study focuses on China due to its particular region that offers the possibility to understand whether these two types of ownership influence the barriers and opportunities for business model innovations. Concretely, the aim of this article is to explore what are the explicit differences between stateowned enterprise and private-owned enterprises in nurturing a business model. Reviewing the existing literature and conducting empirical research based on case studies carried out this exploratory study. The contribution of this paper is to perform a comparison on current business innovation initiatives in Chinese companies, with a focus on the complexity of policy execution, the investment and the leader's contribution in business model innovation and the external financial support. 


\subsection{Business model innovation}

The emergence of the business model concept is associated with the advent of internet and initially used in corporate practice (Zott et al., 2011; George and Bock, 2011). Since then, there are many suggested definitions of business models (c Zott et al., 2011), most of them sharing a common focus on value creation and the close connection with the concept of value.

The business model has three core components: the value proposition, the value creation and delivery system, and the value capture (Richardson, 2008). Identifying these core components would help industry to build a successful business model. An effective business model would lead to a successful company, as referring to the business model analysis, executives identify all of the constituent parts and understand how the model fulfills a potent value proposition in a profitable way (Johnson \& Christensen, 2008). The economic value of a technology will not be fully generated until it's commercialized with a business model (Chesbrough, 2010).

The key of most successful business models is to develop of a 'powerful, focused customer value proposition'. In turn, this requires 'a comprehensive understanding' of your target customer's 'job-to-be-done' (Leavy, 2010). A strength of business model as a planning tool is that it focuses on how the elements fit into a whole system (Magretta, 2002). In Chesbrough's (2007) research, business model performs two important functions: value creation and value capture. It defines a series of activities, from procuring raw materials to satisfying the final consumer, which generates a new product or service. In such a way, net value will be created throughout the various activities (Chesbrough, 2007).

The main reasons for innovating a business model are related to create and acquire more value as well as to address new customers or societal requirements. Every new product development should be joined with the development of a business model, which is defined as 'going to market' and 'capturing value' strategies (Teece, 2010). Björkdahl and Holmén (2013) emphasized that business model innovation refers to creating or reinventing something new or different in doing business. In other words, at least one constitution element of current business model is changed (Eurich et al., 2014). At this stage, Velu (2014) explained business model innovation can "redefine what a product or service is, how it is provided to the customer, and how it is monetized". Therefore, business model innovation can change the mode of competition through altering the performance metrics (Daneels, 2004).

Business model seems easy to imitate in a superficial level. Nevertheless, in practical, implementing a business model may need systems, processes and assets, which is difficult to replicate. Furthermore, a level of opacity may exist that makes it difficult to understand how a business model works in detail. Thirdly, incumbents in the industry may be reluctant to cannibalize existing profits or upset other necessary business relationships (Teece, 2010).

\subsection{State-owned and Private-owned enterprise}

Since the late 1970s, China's economy has undergone reforms. The market- oriented reforms are placed instead of a more planned economy; the private sectors are expanded in China afterwards. Since 1990s, urban areas are selected to restructuring the state-owned enterprise, which is privatization. Since then, the "modern enterprise system" is started (Nolan, 1999).

After two and a half decades of reforms, state-owned enterprise ownership is no longer dominated Chinese business (Ralston, 2006). But the state-owned factor is still plays a significant role in China. The government has the ambitious to build a national team in several pillar enterprises, such as automotive, pharmaceutical, electronics, and petrochemical (Nolan, 2001). This makes China the most adequate scenario for this exploratory study.

Most of the pillar enterprises are still owned by the state in China, such as those in the energy, telecommunication and finance industries. It is relatively easy for them to get support (i.e. financial, policyrelated) from the government. Nevertheless, the execution of innovation may be more challenging, due to the large number of employees and the dispersion of the different departments. Moreover, the internal and external challenges for these enterprises are also sever. The competitions from both internal (i.e. restructure, privateowned enterprise) and external (i.e. domestic private sector, foreign-controlled business sector) are compelling state-owned enterprise innovate business model.

The Chinese definition of the private sector is: "it includes private limited liability corporations, private shareholding corporations, private partnership enterprises and private sole investment enterprises" (Ralston, 2006). Due to the mentioned "open to door" policy, the private sector expanded greatly in China since the late 1970s. Innovations in this type of companies would emerge and evolve in a different manner. In contrast to state- 
owned enterprises, the private-owned enterprises need to discover a suitable business model and try to survive by themselves as the Chinese government to them may give scares support. At this stage, the leader of the private-owned enterprise has to consider a long future version of the enterprise to make a sustainable profit. Thus, the private-owned enterprise would more likely make efforts to invest more money in innovating their business model.

\section{Methodology and data collection}

This research uses a qualitative case study to explore and analyze uncultivated knowledge (Eisehardt, 1989). There are two main activities in the theory development, which are "the formulation of propositions" and "testing whether they can be supported" (Dul \& Hak, 2008). Therefore, this research is based on exploration for theory to discover the current gaps and suggest research propositions. Case study and observation methods help to formulate new propositions, which will be verified in future work.

There are three justifications to select case study as our main research method. Firstly, case study is perhaps the most flexible methods, which could provide a plenty of detailed description of a particular phenomenon (Hakin, 2000). Secondly, this research focuses on the contemporary event, which is identical to the conditions of case study method (Yin, 2014). Thirdly, both single-case and multiple-case study will be used in this research. According to Eisenhardt (1989) and Hagg et al. (1979), many single-case are criticized, as they cannot provide any basis for generalization, while multi-case construct a stronger basis for knowledge building.

\section{$4 \quad$ Empirical case study}

\subsection{Overview of state-owned company A\&B}

\section{Company A:}

Company A has approximate 40 years history in China and around 4000 employees. It is convened to provide blower for either state-owned or private-owned manufacturing industries and serves to diverse fields, such as Petroleum, Metallurgy, Chemical, Electricity, Fertilizer and Pharmacy. In the year 2007, they increased funding and attracted several strategic partners. In the year 2010, this company was listed.

The traditional business model of Company A was based on direct product sales. Currently, this company not only sells products but also provides services to its consumers. Moreover, they have innovated their business model in the following three aspects:

- The main source of business profit has changed its focus from equipment, physical power and technical ability to brand value, knowledge and human capital.

- A previous technical-oriented approach was modified to extend business boundaries and adopt a more customer-oriented approach

- Improvements in the integration of resource capability from a self-owned resource based to a integration external resource

As the competition from both internal and external are getting fierce, company A tried to make a sustainable profit to survive. As a state-owned enterprise, company A could get continues financial support from the state. Thus, they could have a better policy execution. For example, Company A constructed an eco-system factory. It's difficult to execute for private-owned enterprise because of the lack of profit stimulation. Companies need to invest a huge amount of money to build the system and the profit would mostly need to be expected after several years. Apparently, it's a burden for most of small to medium private owned companies. However, it's much easier for state-owned company to get the Land Use Right and the local government would support for their construction.

\section{Company B:}

Company B is a state-owned numerical machine tool industry. It was founded in the year 1965 and the current employees are around 3500 people. In the year 1995, company B upgraded from numerical machine tool factory to numerical machine tool company. In the year 1998, company B experienced shareholding reform and went to the public. In the year 2007, company B upgraded by means of merger and acquisition other small numerical machine tool company. During the merger and acquisition, the government offered enormous supporting. Specifically, the government let the company reorganizing their core product and abandons their deficit product. It is worth to mention that the government paid for their deficit product and invests huge money to their core product. 
The current operating performance of Company B is barely satisfactory. For one thing, most of the numerical system needs to be imported from abroad, as the technology in the local market cannot satisfy the high requirements in precision yet. Besides, some high precision machine tool parts are also need to be imported from abroad as well. Thus, the profit margin is very low. For another, most of the senior employees in this stateowned company have life-long position. Even if they don't work that hard, the company normally will not layoff them until they get formally retired. The system makes the senior employee doesn't have a passion to make innovation. In contract, although most of the joiner employees are signed short-term renewable contract, they don't have a protection of the position. In addition, as the working condition of numerical machine tool industry is terrible, fewer striplings are willing to choose this job. For the current striplings work as apprentice, they mostly would like to change a job afterwards.

\subsection{Overview of private-owned company C\&D}

\section{Company C:}

Company $\mathrm{C}$ is a large-scale equipment manufacturing enterprises, which was founded in the year 1966. They mainly produce numerical machine tool part; energy equipment; miner equipment; engine; compressor; wind turbine; track and so on. Company $\mathrm{C}$ was a state-owned enterprise until the year 2004. After that, Company C reformed to a private-owned enterprise and attracted several strategic partner. Currently, Company $\mathrm{C}$ owns dozens of subsidiary company.

As a leading casting enterprise in China, Company $\mathrm{C}$ has a deep understanding of their advantage and insisted in their core competitiveness continuously. They do expand their business to new areas such as chemical and biomedical engineering, but casting still takes the largest market share of their products.

During the qualitative research, the author identified that there exist two reasons to make Company $\mathrm{C}$ successful. Firstly, the leader has a powerful ability to judge the development direction of the industry. For instance, in the year 2012, the leader decided to build their company as an innovation enterprise. They explored their technology to digitization and intellectualization. In the year 2015, the Chinese state issued a policy - building the Chinese industry digitization and intellectualization by 2025. This new policy for manufacturing companies is exactly accordance to the policy company $\mathrm{C}$ issued three years ago. Secondly, the efficient to execute a new policy of Company C is remarkable. For example, in November 2015, the leader decided to change their management pattern. Formerly, their management mode is a traditional way that the supervisors set a profit target and the employees follow their instruction to fulfill the task. However, the new business model is to divide one department into several teams, each team includes 3 to 4 people. The team would find their customers by themselves. They changed their working pattern from passive to initiative. The more contract they signed, the higher deduction wage they will get. This management mode motivates every employee to make profit, but this innovation put the people waiting for others instruction into a difficult situation. Surprised, Company C only use three month to execute this new policy.

\section{Company D:}

Company $\mathrm{D}$ is a traditional private-owned family firm. Their business is mainly to produce numerical machine tool part, as well as the numerical system. The main capital resource is from the profit of traditional manufacturing product (i.e. industrial robot, hydraulic system equipment, sensor etc.). They also produce customized product. This company was founded in 1993, it used be a family industry, with a single ownership structure. From 2015, their subsidiary company is preparing for IPO. In the future, Company D will keep working as single ownership structure but their subsidiary company will work as board of directors and operated by CEO.

The main customer of this company is aerospace and military industry. Company D has ambitious to replace the market share of import product from Japan and German. Family enterprise has widespread characteristics that their leader has absolute authority to decide the future development of the enterprise. That situation leads a risk that the leader may make a wrong decision. For instance, the leader in Company D decided to produce numerical control system. However, this is an advance technique that difficulties are not fully overcome yet. This company spends more than ten years in this technique, but the profit is unsatisfactory. Moreover, comparing with state-owned enterprise. It is more difficult for private-owned companies to get funding from the government. Mostly, Company D needs to survive all on them own.

\subsection{Findings and discussion}

\section{Leader's perspective in business model innovation}

There exist a policy for state-owned company that the state or the local government nominates the leader. In this qualitative research, we explored another reason makes Company A succeed, which is the future perspective and the execution status of the leader's idea. Comparing the leader between company A and company B. There 
exist a significant difference. Company A doesn't change their leader for 14 years, which makes this leader's strategy and target carried out in a most effective way. In contract, Company B changes their leader every four to five years. This phenomenon makes each leader only consider the company performance during his term of office.

Both of the two private-owned enterprises have the common characteristics: the leader has the absolute authority to decide the enterprise's development direction. Company $\mathrm{C}$ has a board of directors to decide their innovated policy. Therefore, the leader would have an opportunity to hear different voice and make a proper decision. In contract, Company D is a family industry; it is difficult to make the leader change the decision, especially when it is a wrong one.

\section{Complexity of policy execution in business model innovation}

In empirical study, the authors discovered that private-owned enterprise has a significant high efficient in execution innovated policy. For instance, Company A needs to take several years to implement an innovated idea. Because the authority is more divided comparing with the private-owned company. Thus, it takes a longer time to get the idea approved by the leader, let along to implement the idea. Nonetheless, it only takes several months for Company $\mathrm{C}$ to change their management mode. One of the possible reasons is the employees in state-owned enterprise are mostly have the life-long position. They lack a sense of crisis for the position.

\section{Investment and the financial support}

Through the case study, we discovered that private-owned enterprises are very difficult to get financial support from the state. Therefore, to make a sustainable profit, private-owned enterprises have a stronger eager to innovate their ideas and business model. In contract, state-owned enterprise could get funding much easier from the government. This would lead two situations: the advantage is companies would be much easier to realize innovation, as they would get support from local government and could get benefit from preferential policies. The disadvantage is that employees' working attitude might be passive. Because of their life-long position would make them have a financial guarantee from the government no matter what are their work efficiency is.

\section{Concluding remarks}

Through the empirical study, the authors identified that the private-owned company has higher innovation ability. It is very difficult for private-owned enterprise to get large amount of funding support from the state. Therefore, they have much stronger eager to innovate new technology as well as their business model to make a sustainable profit. Moreover, private-owned enterprise has a significant high efficient in execution innovated policy. Because most of employees signed short-term renewable contract, they have a sense of crisis for their position. Additionally, the authority in state-owned enterprise is more divided than the private-owned company. That result in a longer period to execute a policy. Furthermore, the leader's perspective of the innovation not only depends on the leader's personal ability, but also depends on their nomination duration. This phenomenon is more general in state-owned enterprise.

In this research, the case study is mainly focus on the company's current situation. In future works, we plan to conduct further research in government policy and legalization. Finally, we will design a tool to instruct both kind of enterprise to carry forward their advantages, especially how to maximize their resources.

\section{Reference:}

Björkdahl, J. and Holmén, M. (2013) 'Editorial: business model innovation - the challenges ahead', International Journal of Product Development, Vol. 18, No. 3, p.213.

Bock, A. J., Opsahl, T., George, G., \& Gann, D. M. (2012). The effects of culture and structure on strategic flexibility during business model innovation. Journal of Management Studies, 49(2), 279-305.

Chesbrough, H. (2007). Business model innovation: it's not just about technology anymore. Strategy \& Leadership, 35(6), 12-17.

Chesbrough, H. (2010). Business model innovation: Opportunities and barriers. Long Range Planning, 43(23), 354-363.

Clayton, C. \& Michael, R., 2003. The innovator's solution: Creating and sustaining successful growth, Harvard Business School Press.

Daneels, E. (2004) Disruptive technology reconsidered: a critique and research agenda. Journal of Product Inno- 
vation Management, 21, 246-258.

Dul, J., \& Hak, T. (2008). Case Study Methodology in Business Research. New York (Vol. 129).

Eurich, M., Weiblen, T., \& Breitenmoser, P. (2014). A Six-Step Approach to Business Model Innovation. International Journal of Entrepreneurship and Innovation Management, 18(4), 330-348.

Eisehardt, M., 1989. Building theories from case study research. The Academy of Management Review, 14(4), pp.532-550.

George, G. \& Bock, A.J. (2011). The Business Model in Practice and its Implications for Entrepreneurship Research. Entrepreneurship, theory and practice, January 2011, pp 1042-2587.

Hakin, C. 2000. Research Design: Succesful Designs for Social Economics Research: Routledge.

Hagg, I. and Hbdlund, G. (1979). Case studies in Accounting Research, Accounting, Organization and Scoiety, 4(I/2), 135-143.

Johnson, M. W., \& Christensen, C. M. (2008). Reinventing your business model, (December), 50-60.

Lin JY, Cai F, Li Z. 2001. State-Owned Enterprise Reform in China. Chinese University Press: Hong Kong.

Leavy, B. (2010). A system for innovating business models for breakaway growth. Strategy \& Leadership, $38(6), 5-15$.

Magretta, J. (2002). Why Business Models Matter A Conversation with Robert Redford. Harvard Business Review, 80(5), 86-92, 133.

Mitchell, D., \& Coles, C. (2003). The ultimate competitive advantage of continuing business model innovation. Journal of Business Strategy, 24(5), 15-21.

Nolan P. 2001. China and the Global Economy. Palgrave: New York.

Nolan P and Wang X., 1999. Beyond Privatization: Institutional Innovation and Growth in China's Large StateOwned Enterprises. World Development Vol. 21, No. 1, pp. 169-200.

National Bureau of Statistics. 2003. China Statistical Yearbook 2002 . China Statistics Press: Beijing.

Richardson, J. (2008). The business model: an integrative framework for strategy execution. Strategic Change, 17(5-6), 133-144.

Ralston David A and Tong Jane Terpstra, 2006. Today's state-owned enterprises of China: are they dying dinosaurs or dynamic dynamos? Strategic Management Journal. 27: 825-843

Schaltegger, S., Lüdeke-Freund, F., \& Hansen, E. G. (2012). Business cases for sustainability: the role of business model innovation for corporate sustainability. International Journal of Innovation and Sustainable Development, 6(2), 95-119.

Schneider, S., \& Spieth, P. (2013). Business model innovation: towards an integrated future research agenda. International Journal of Innovation Management, 17(01), 1340001.

Teece, D. J. (2010). Business models, business strategy and innovation. Long Range Planning, 43(2-3), 172194.

Velu Chander and Jacob Arun, 2014. Business model innovation and owner-managers: the moderating role of competition. R\&D Management.

Yin , Robert K .(2014): Case Study Research . Design and Methods. 5th edition. Zeitschrift Für Personalforschung, 26(1), 93-96.

Zott, C., Amit, R. \& Massa, L. (2011). The Business Model: Recent Developments and Future Research. Journal of Management Vol. 37 No. 4, July 2011, pp. 1019-1042 